\title{
THE RIGHT OF ACCESS TO A COURT IN UKRAINE IN THE LIGHT OF THE REQUIREMENTS OF THE CONVENTION FOR THE PROTECTION OF HUMAN RIGHTS AND FUNDAMENTAL FREEDOMS
}

\section{Maryna Stefanchuk, Oleksandr Hladun and Ruslan Stefanchuk}

Summary: 1. Introduction. - 2. The Right to a Fair Trial and the Inconsistency of the System of Local General Courts with the New Administrative-Territorial Structure of the District Level. - 3. Lack of Clear and Understandable Criteria for Delimiting the Subject-Matter Jurisdiction of Cases in Terms of the Right to a Fair Trial. - 4. The Insignificance of the Case and the Court Fee as Procedural Restrictions on the Right of Access to Court. -5 . Staffing of the Judiciary and the Level of Public Confidence in the Judiciary as Elements of Ensuring the Right of Access to Justice. - 6. Introduction of a Lawyer's Monopoly on the Representation of Another Person in Court in Terms of the Right to a Fair Trial. - 7. Motivation of Court Decisions in the Aspect of the Right to a Fair Trial. - 8. Conclusions.

To cite this note: $M$ Stefanchuk, $O$ Hladun, $R$ Stefanchuk 'The right of access to a court in Ukraine in the light of the requirements of the Convention on Protection human rights and fundamental freedoms' 2021 1(9) Access to Justice in Eastern Europe 186-198. D0I: 10.33327/AJEE-18-4.1-n000052

To link to this note: https://doi.org/10.33327/AJEE-18-4.1-n000052

Submitted on 10 Dec 2020 / Revised 24 Jan 2021 / Revised 14 Feb 2021 / Approved 22 Feb 2021 / Published online: 01 Mar $2021 \quad$ View data

Submit your article to Access to Justice in Eastern Europe http://ajee-journal.com/submissions

\section{CONTRIBUTORS}

All three authors contributed equally to the intellectual discussion underlying this paper, literature exploration, writing, data collection, analysis, and interpretation, reviews, and editing, and accept responsibility for the content of the paper.

\section{CONFLICTS OF INTEREST}

The authors declare no conflict of interest of relevance to this topic.

\section{DISCLAIMER}

The authors declare that they were not involved in the analysed law drafts within their collaboration with the legislative body. 


\title{
THE RIGHT OF ACCESS TO A COURT IN UKRAINE IN THE LIGHT OF THE REQUIREMENTS OF THE CONVENTION FOR THE PROTECTION OF HUMAN RIGHTS AND FUNDAMENTAL FREEDOMS
}

\author{
Stefanchuk Maryna \\ Dr. Sc. (Law), Assoc. Prof., Law School, \\ Taras Shevchenko National University of Kyiv, Ukraine \\ Hladun Oleksandr \\ $\mathrm{PhD}$ (Law), Senior Research Fellow, \\ Secretariat of the Verkhovna Rada of Ukraine

\section{Stefanchuk Ruslan} \\ Dr. Sc. (Law), Academic of \\ The National Academy of Legal Sciences of Ukraine
}

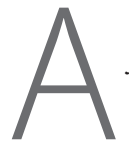

bstract This note considers the national legal provisions that regulate the procedure and features of a person's appeal to the court to protect their rights. Taking into account the provisions of Art. 6 of the Convention for the Protection of Human Rights and

Fundamental Freedoms (ECHR) regarding the right to a fair trial and the case-law of the European Court of Human Rights (ECtHR) on its interpretation, key threats to the effective exercise of access to justice in Ukraine have been identified. The problem of the inconsistency of the system of local general courts with the new administrative-territorial structure at the district level is highlighted. It is demonstrated how the lack of clear and understandable criteria for distinguishing the subject matter jurisdiction of cases affects the ensuring of the human right to an effective court. Particular attention is paid to the staffing of the judiciary and the low level of public confidence in the judiciary. The authors have analysed the validity of the application of such procedural restrictions as the court fee for filing a lawsuit and the classification of 'insignificant cases', which are impossible to appeal. On this basis, it is concluded that the existence of such restrictions on access to court cannot be considered a violation of the right to a fair trial if such restrictions are justified and proportionate to the lawful purpose of their establishment and do not violate the essence of this right. The features of the introduction in Ukraine of a lawyer's monopoly on the representation of another person in court, as well as the practice of the ECtHR regarding the possibility of recognising such restrictions as a violation of the right to a fair trial, are analysed. Legislative initiatives to improve the motivation of decisions by the courts are highlighted. It was concluded that the provisions aimed at forming a more responsible attitude of judges to the consideration of cases and making reasoned decisions, as well as solving the problem of excessive load on judges, are a prerequisite for ensuring the right to a fair trial.

Keywords: human rights and responsibilities, fair trial, access to justice, case-law of the European Court of Human Rights, procedural restrictions, court jurisdiction, proportionality, legal purpose, court fees, lawyer monopoly. 


\section{INTRODUCTION}

According to Art. 6 of the ECHR, everyone has the right to a fair and public hearing within a reasonable time by an independent and impartial tribunal established by law, which shall decide on his/her civil rights and obligations or establish the reasonableness of any criminal charges against him/her.

The right of access to a court and trial as an element of the broader right to a fair trial is one of the fundamental guarantees of the exercise of natural human rights and freedoms. After all, the inaccessibility of judicial control over the proper and conscientious realisation of their rights and responsibilities by all participants in public relations would result in anomie in the state. According to the provisions of Art. 55 of the Constitution of Ukraine, human and civil rights and freedoms are protected by the court. Access to justice for every person is ensured in accordance with the Constitution of Ukraine and in the manner prescribed by the laws of Ukraine.

A textbook example of the European Court of Human Rights' interpretation of the right of access to a court is the decision in Golder $v$ the United Kingdom

It would be inconceivable, in the opinion of the Court, that Article 6 para. 1 (art. 6-1) should describe in detail the procedural guarantees afforded to parties in a pending lawsuit and should not first protect that which alone makes it in fact possible to benefit from such guarantees, that is, access to a court. The fair, public and expeditious characteristics of judicial proceedings are of no value at all if there are no judicial proceedings. ${ }^{1}$

It is worth noting that the right of access to a court has never been considered an absolute one. Its implementation is possible depending on compliance with certain restrictions, which, in turn, must be legal, reasonable, and serve a legitimate purpose. As noted by the ECtHR in Guérin v France

these limitations must not restrict exercise of the right in such a way or to such an extent that the very essence of the right is impaired. They must pursue a legitimate aim and there must be a reasonable proportionality between the means employed and the aim sought to be achieved. ${ }^{2}$

At the same time, the provisions of the national legislation of Ukraine, which regulate the procedure and features of a person's appeal to the court to protect their rights, contain certain threats to the effective exercise of the right to access to court in Ukraine, taking into account the provisions of Art. 6 of the ECHR and case-law of the ECtHR on their interpretation. Among these threats, first of all, is the inconsistency of the system of local general courts with the new administrative-territorial structure of the district level; lack of clear and understandable criteria for distinguishing the subject matter jurisdiction of cases; features of the legal regulation of such procedural restrictions as the court fee for filing a claim and categorising the case as insignificant, which makes it impossible to appeal it; problems of staffing of the judiciary and low level of public confidence in the judiciary; the introduction of a lawyer's monopoly on the representation of another person in court. The reasons and preconditions for imposing such restrictions on access to justice and their relation to the right to a fair trial will be discussed later in this article.

1 Golder $v$ the United Kingdom App no 4451/70 (ECtHR, 21 February 1975) para 35 <http://hudoc.echr. coe.int/eng?i=001-57496> accessed 19 February 2021.

2 Guérin v France App no 25201/94 (ECtHR, 29 July 1998) para 37 <http://hudoc.echr.coe.int/ eng?i=001-58204> accessed 19 February 2021. 


\section{THE RIGHT TO A FAIR TRIAL AND THE INCONSISTENCY OF THE SYSTEM OF LOCAL GENERAL COURTS WITH THE NEW ADMINISTRATIVE-TERRITORIAL STRUCTURE OF THE DISTRICT LEVEL}

A key aspect of the practical implementation of the human right of access to justice is the proper organisation of the judiciary. When assessing the state's fulfilment of its obligations to ensure the right to a fair trial, the ECtHR assumes that the right of access 'by its very nature calls for regulation by the state, regulation which may vary in time and in place according to the needs and resources of the community and of individuals. ${ }^{3}$ Art. 125 of the Constitution of Ukraine stipulates that the judicial system in Ukraine is based on the principles of territoriality and specialisation and is determined by law. Thus, the peculiarities of the administrative-territorial system have a significant impact on the organisation of the judiciary and the system of its bodies.

Art. 19 of the Law of Ukraine 'On the Judiciary and the Status of Judges' stipulates the grounds for the formation or liquidation of the court. These grounds include changes in the judicial system defined by this Law, the need to ensure access to justice, optimise state budget expenditures or change the administrative-territorial structure. The general principles of this system, including the division of the territory of Ukraine into such components as the Autonomous Republic of Crimea, regions, districts, cities, districts in cities, towns, and villages, are enshrined in Art. 133 of the Constitution of Ukraine. At the same time, the most acute problem for ordinary citizens remains access to local general courts, which are district courts formed in one or more districts or districts in cities, or in a city, or in a district (districts) and a city (cities). District, inter-district, district in cities, city, city-district courts continue to exercise their powers until the formation and commencement of the local district court, whose jurisdiction extends to the relevant territory.

The formation and liquidation of districts, the establishment, and change of boundaries of districts and cities, the classification of settlements as cities, the naming and renaming of settlements and districts belong to the powers of the parliament (Art. 85 of the Constitution of Ukraine). In mid2020, the Verkhovna Rada of Ukraine, at the request of the Government, substantially revised the system of administrative-territorial organisation at the district level. Four hundred and ninety districts were liquidated, and 136 new districts were created. Therefore, the logical question is to bring the system of local courts in line with the new district division because currently, several district courts can function within one district, and the territorial jurisdiction of some district courts can cover the boundaries of several newly created districts.

The problem of renewal of district executive bodies was solved quite quickly in accordance with the order of the Cabinet of Ministers of Ukraine No. 1635-p on reorganisation and formation of district state administrations. ${ }^{4}$ At the same time, national legislation establishes a special procedure for the formation and liquidation of courts: a court is formed, reorganised, and liquidated by a law, the draft of which is submitted to the Verkhovna Rada of Ukraine by the President of Ukraine after consultations with the High Council of Justice. Thus, until the formation of a new system of district courts, which will correspond to the changed district administrative-territorial structure, the existing district courts continue to exercise their powers within the previous administrative-territorial structure. This legal

3 Stanev v Bulgaria App no 36760/06 (ECtHR, 17 January 2012) para $230<$ http://hudoc.echr.coe.int/ eng?i=001-108690 > accessed 19 February 2021.

4 The order of the Cabinet of Ministers of Ukraine No 1635-p on reorganization and formation of district state administrations of 16 December $2020<$ https://www.kmu.gov.ua/npas/pro-reorganizaciyu-tautvorennya-rajonnih-derzhavnih-administracij-1635-161220> accessed 19 Fbruary 2021. 
position was also expressed by the Council of Judges of Ukraine in a corresponding letter. ${ }^{5}$ However, until the status quo is legally secured in this area, the right of access to a local court cannot be considered adequately protected. Therefore, the relevant draft law on this issue was submitted by the Government to the Verkhovna Rada of Ukraine. ${ }^{6}$

However, a temporary (transitional) settlement of the territorial jurisdiction of district courts does not abolish the positive obligation of the state to create a clear and accessible system of these courts, which would correspond to the administrative-territorial structure of the state. Thus, the decision of the ECtHR in Airey $v$ Ireland states that

\begin{abstract}
hindrance in fact can contravene the Convention just like a legal impediment (abovementioned Golder judgment, p. 13, para. 26). Furthermore, fulfilment of a duty under the Convention on occasion necessitates some positive action on the part of the State; in such circumstances, the State cannot simply remain passive and "there is ... no room to distinguish between acts and omissions". The obligation to secure an effective right of access to the courts falls into this category of duty.?
\end{abstract}

It is also worth noting that the current legislation provides reliable guarantees of the right to a fair trial in the event of liquidation of a particular court. Thus, on the basis of Art. 147 of the Law of Ukraine 'On the Judiciary and the Status of Judges', the liquidated court, within one month from the date of its termination, transfers to the newly formed court materials and documents related to the exercise of its powers, in particular, archival cases, the storage term of which has not yet expired, documents not completed in the office, as well as personnel documents in paper and electronic form, library funds. Court cases and materials of proceedings in the possession of the liquidated court are to be transferred immediately, before the first day of work of the newly formed court.

\title{
3 LACK OF CLEAR AND UNDERSTANDABLE CRITERIA FOR DELIMITING THE SUBJECT-MATTER JURISDICTION OF CASES IN TERMS OF THE RIGHT TO A FAIR TRIAL
}

A common and acceptable restriction on the right of access to a court is the need to comply with the procedural rules established at the state level. The case-law of the ECtHR enshrines an approach whereby procedural rules concerning the subject matter of the dispute or the application of such rules should not prevent the parties from obtaining available judicial protection. For example, in Shestopalova $v$ Ukraine, the ECtHR found a violation of Art. 6 para. 1 of the Convention concerning the applicant's right of access to a court. The Court stated that

the applicant was able to institute proceedings before the domestic courts but that they finally failed to rule on the merits of her reinstatement claim, having found no jurisdiction in respect of the matter, notwithstanding the fact that the procedural admissibility requirements had been complied with. ${ }^{8}$

\footnotetext{
5 The Letter of the Head of the Council of Judges of Ukraine No 9pc-466/20-виx of 22 July $2020<$ http:// rsu.gov.ua/uploads/news/listrsuteritorialnapidsudnist-94cb75de58.pdf> accessed 19 February 2021.

6 Draft Law of Ukraine 'On Amending some Legislative Acts of Ukraine Concerning Settling Separate Questions of Activity and Organization of State Bodies, Local Self-Government in Connection with Establishing (Liquidation) of Districts' of 15 June 2020 No $3651<$ http://w1.c1.rada.gov.ua/pls/zweb2/ webproc4_1?pf3511=69133> accessed 19 February 2021.

7 Airey $v$ Ireland App no 6289/73 (ECtHR, 9 October 1979) para $25<$ http://hudoc.echr.coe.int/ eng?i=001-57420> accessed 19 February 2021.

8 Shestopalova $v$ Ukraine App no 55339/07 (ECtHR, 21 December 2017) para $18<$ http://hudoc.echr.coe. int/eng?i=001-179558> 19 February 2021.
} 
Obviously, the lack of clear and understandable criteria for delimiting the subject-matter jurisdiction of cases should be interpreted as a violation of the principle of legal certainty, which is part of the rule of law. After all, the consequence of a violation of jurisdictional rules is either grounds for refusing to initiate proceedings or grounds for closing the proceedings that had been opened, depending on the stage of the proceedings when such a violation was revealed. As a result, the person is deprived of the opportunity to apply to an authorised court to resolve a dispute regarding his/her rights and obligations. Insufficient legal certainty of subject-matter jurisdiction creates difficulties not only for persons applying to the court for protection but also for judges. In such circumstances, the provisions of national law on the court's obligation to explain to the plaintiff, to whose jurisdiction the case falls, if the proceedings are closed due to the non-jurisdiction of such a court, remain ineffective (Part 1 of Art. 239 of the Code of Administrative Procedure, Part 1 of Art. 256 of the Civil Procedure Code, Part 2 of Art. 231 of the Commercial Procedure Code).

The problem of determining judicial jurisdiction to hear cases is not new for Ukraine. Unfortunately, we can state that even a large-scale update of the procedural legislation at the end of $2017^{9}$ did not lead to significant improvement of the situation. This is evidenced by the extensive practice of the Supreme Court, which by law has the function of ensuring the uniform application of legal provisions by courts of different specialisations in the manner prescribed by procedural law. The Grand Chamber of the Supreme Court has heard almost 3,000 jurisdictional disputes and formed more than 300 legal positions. In some cases, the Grand Chamber of the Supreme Court itself deviated from its conclusions on the application of the rule of law to determine the judicial jurisdiction of cases. At the same time, according to Judge O. Kibenko,

in resolving these issues, the Supreme Court takes the position that the criterion for determining jurisdiction should be as simple and clear as possible, ie such that can be applied at the time of filing a lawsuit, and not after the court has already begun hearing the case. ${ }^{10}$

The ECtHR, in assessing the compliance of states with the requirements to ensure the right to a fair trial, also draws attention to the observance by national courts of the rules of judicial jurisdiction enshrined in law. In particular, in Sokurenko and Strygun v Ukraine, the Court has concluded that

having overstepped the limits of its jurisdiction, which were clearly laid down in the Code of Commercial Procedure, the Supreme Court could not be considered the "tribunal established by law" within the meaning of Article 6 para. 1 of the Convention in respect of the impugned proceedings. ${ }^{11}$

In view of the above and in order to ensure the human right of access to court, we believe that domestic procedural law needs to be improved, in particular, by establishing presumed criteria for delimiting the subject-matter jurisdiction of cases, guaranteeing the mechanism of a case transfer to a court of another jurisdiction.

9 The Law of Ukraine No 2147-VIII of 3 October 2017 'On Amendments to the Commercial Procedural Code of Ukraine, the Civil Procedure Code of Ukraine, the Code of Administrative Procedure of Ukraine and other legislative acts' <https://zakon.rada.gov.ua/rada/show/2147-19> accessed 19 February 2021.

10 'Jurisdiction of disputes, insignificant cases and application of the principle of the rule of law by judges of the Supreme Court' (Verkhovnyi Sud, 26 January 2021) <https://supreme.court.gov.ua/supreme/prescentr/news/1062315> accessed 19 February 2021.

11 Sokurenko and Strygun v Ukraine App nos 29458/04 and 29465/04 (ECtHR, 11 December 2006) para 28 <http://hudoc.echr.coe.int/eng?i=001-76467> accessed 19 February 2021. 


\section{THE INSIGNIFICANCE OF THE CASE AND THE COURT FEE AS PROCEDURAL RESTRICTIONS ON THE RIGHT OF ACCESS TO COURT}

Among the procedural restrictions on access to court proceedings, the impossibility of cassation appeal of court decisions in cases of insignificant complexity (insignificant cases) is often singled out. However, we believe that the restriction of the right to cassation should not be equated with the restriction of access to justice, as such an approach fully complies with the requirements of Art. 6 of the ECHR. First of all, it should be borne in mind that the Convention, in general, does not provide for a direct obligation of the state to establish appellate and cassation courts. However, in the case of such institutions, their activities usually have to meet the standards of the right to a fair trial. At the same time, the ECtHR has repeatedly stated that

Given the special nature of the Court of Cassation's role, which is limited to reviewing whether the law has been correctly applied, the Court is able to accept that the procedure followed in the Court of Cassation may be more formal [...]

For example, such a position was enshrined in Levages Prestations Services v France. ${ }^{12}$

One of the criteria for classifying cases as insignificant is the value of the claim, which cannot exceed one hundred times the subsistence minimum for able-bodied persons (UAH 227,000 in 2021). This should also not be considered as a violation of the right of access to court. For example, in Brualla Gomez de la Torre $v$ Spain, the ECtHR stated

The Court considers legitimate the aim pursued by this statutory amendment, namely increasing the financial threshold for appeals to the Supreme Court in this sphere, so as to avoid that court's becoming overloaded with cases of lesser importance. ${ }^{13}$

The relevant provisions of Ukrainian legislation on this issue have already been the subject of an assessment by the ECtHR, which has recognised them as not violating the essence of the right of access to a court. Thus, in Azyukovska v Ukraine, the Court found that

the new admissibility requirement had been sufficiently foreseeable to the applicant at the time when she sought to avail herself of the right to appeal before a court of cassation [...] The appeal on points of law to the Supreme Court had been made after the applicant's claims had been considered by the Novomoskovsk Court and the Dnipropetrovsk Regional Court of Appeal, each of which had full jurisdiction. Further, the Supreme Court noted that the applicant had not demonstrated the existence of grounds which would have justified granting a leave to appeal on an exceptional basis. ${ }^{14}$

For developing countries, including Ukraine, a serious challenge is to strike a balance between the private interest of individuals in applying to court to protect their rights and the financial capacity of the state to maintain the judiciary. A common procedural restriction on the right of access to a court is the obligation to reimburse court costs in advance by the party initiating the dispute. The Annex to Recommendation No. R (81) 7 of the Committee of Ministers of the Council of Europe sets out a number of principles concerning court costs in the context of facilitating access to justice. In particular, the admission to the proceedings should not depend on the payment by a party to the state of a sum of money

12 Levages Prestations Services v France App no 21920/93 (ECtHR, 23 October 1996) para $48<$ http:// hudoc.echr.coe.int/eng?i=001-58065> accessed 19 February 2021.

13 Brualla Gomez de la Torre v Spain App no 26737/95 (ECtHR, 19 December 1997) para $36<$ http:// hudoc.echr.coe.int/eng?i=001-58127> accessed 19 February 2021.

14 Azyukovska v Ukraine App no 26293/18 paras 24-25 <http://hudoc.echr.coe.int/eng?i=001-187765> accessed 19 February 2021. 
that is unreasonable in view of the issue in the case. To the extent that court costs are a clear obstacle to access to justice, they should, if possible, be reduced or eliminated. ${ }^{15}$

In the context of the right of access to court, a key element of court costs is the court fee charged for filing applications and complaints to the court. In Ukraine, the basic social standard, the size of which serves as a value for calculating the rate of court fees, is the subsistence minimum for able-bodied persons, established by law on 1 January of the calendar year in which the application or complaint is filed with the court. In the case-law of the ECtHR, the requirement to pay a court fee in connection with the filing of a lawsuit is not considered as a restriction of the right of access to court, which undermines the very essence of this right. However, the amount of the fee, calculated taking into account the specific circumstances of the case, including the applicant's ability to pay it, and the stage of the proceedings at which this restriction was imposed are factors in determining whether the person exercised his/her right of access to court (see, for example, Kreuz v Poland). ${ }^{16}$ Therefore, the rules laid down in national law as to the amount of such costs must be proportionate to the objectives of Art.6 para. 1 of the ECHR.

According to the Law of Ukraine of 8 July 2011 No. 3674-VI 'On Court Fees', the maximum rate of court fees for filing a property claim to the local general court for individuals or entrepreneurs is a subsistence minimum of EUR 5 (in 2021 - UAH 11,350), and for legal entities, a subsistence minimum of EUR 350 for able-bodied persons (UAH 794,500). When filing an appeal and cassation appeal, the rate of court fees is increased by $50 \%$ and $100 \%$, respectively. At the same time, the Law provides for cases in which the court fee is not collected, as well as the categories of persons who are exempt from paying the court fee during the consideration of the case in all courts. The provisions of the Law, on the basis of which it is possible to defer and pay an instalment payment of court fees, reduce its amount, or release from payment based on the property status of the party, are socially justified. This can happen, in particular, in cases where the court fee exceeds five per cent of the annual income of the plaintiff - an individual during the previous calendar year or if the plaintiffs are members of a low-income or large family. It is the proportionality of the court fee to income, financial and financial status, social status of the person that is a guarantee of permissible restriction of the right of access to court. Otherwise, it may be considered incompatible with the content of such a right. Thus, the court's unjustified refusal to reduce the amount of the appeal fee was found to be in breach of Art. 6 para. 1 of the ECHR in Kniat $v$ Poland. ${ }^{17}$ The Court stated that the domestic courts had failed to strike a proper balance between, on the one hand, the state's interest in collecting court fees and, on the other hand, the applicant's interest in continuing her appeal against the divorce decree.

\section{STAFFING OF THE JUDICIARY AND THE LEVEL OF PUBLIC CONFIDENCE IN THE JUDICIARY AS ELEMENTS OF ENSURING THE RIGHT OF ACCESS TO JUSTICE}

At the present stage of development of the domestic judicial system, one of the most acute problems is the quantitative and qualitative staffing of the judicial system, which has a significant impact on the implementation of the constitutionally guaranteed right of access to justice.

15 Reccomendation No R (81) 7 Of the Committee of Ministers of the Council of Europe on measures to facilitate access to justice of 14 May $1981<\mathrm{https} / / /$ court.gov.ua/userfiles/08.pdf> accessed 19 February 2021.

16 Kreuz $v$ Poland App no 28249/95 (ECtHR, 19 June 2001) para $60<$ http://hudoc.echr.coe.int/ eng?i=001-59519> accessed 19 February 2021.

17 Kniat $v$ Poland App no 71731/01 (ECtHR, 26 October 2005) paras 45-47 <http://hudoc.echr.coe.int/ eng?i=001-69901 > accessed 19 February 2021. 
A long-term judicial reform in Ukraine has so far not yielded the desired results. The vast majority of courts remain understaffed, which significantly increases the burden on other judges and extends the timeframe of case consideration. According to the State Judicial Administration of Ukraine, as of 1 January 2020, 2,044 positions of judges were vacant. In the first half of 2020 alone, 119 judges expressed a desire to resign. Approximately 10 courts in Ukraine do not work at all due to the lack of judges with powers.

At the same time, the body authorised by the Law to select candidates for appointment to the position of a judge (High Qualification Commission of Judges of Ukraine) has not been operating for more than a year. The powers of the members of the commission were terminated on 7 November 2019. That is why the urgent task of the state is to form the composition of such a commission on the basis of a transparent and objective competition and to launch a full-fledged selection of judges as soon as possible. The Verkhovna Rada of Ukraine is already considering a draft law aimed at improving the procedures for the formation and operation of judicial authorities and resuming competitions for judges. ${ }^{18}$ Therefore, the realisation of the right of citizens to access to court depends on how balanced the approach of the parliament to rebuilding the institutional foundations of the judiciary in Ukraine will be.

Effective access to justice is no less determined by the level of public confidence in the judiciary. Unfortunately, the results of sociological measurements indicate serious problems in this area. In the fall of 2020, the Razumkov Centre's sociological service conducted a specialised representative survey, 'Attitudes of Ukrainian citizens to the judiciary.' ${ }^{19}$ Some of the conclusions of this study are the following.

Since most citizens do not have personal experience of communicating with the courts and determine their attitude to the judiciary on the basis of other people's experience or information in the media, the attitude of the population as a whole to the judiciary is negative while the level of trust is one of the lowest among state and social institutions. However, the level of trust of citizens who have had their own recent experience of communicating with the courts is much higher.

This situation clearly demonstrates the need to fill the judicial system as soon as possible with professional and honest judges, whose activity will promote the authority of the judiciary, respect for court decisions, and restore public confidence in the state in the face of the judiciary.

The ways to achieve a high level of public confidence in the judiciary in Ukraine vary: from a radical 'reset' to a position in which civil society's distrust of the courts in Ukraine is not a sufficient basis for their 'reset' due to the current crisis. It should be recalled that this crisis was provoked, in part, by the reform aimed to improve the activities of judicial authorities, which was enshrined in the provisions of Law No. 193-IX on changing the number and subjects of appointment of the High Qualifications Commission of Judges of Ukraine. The provisions of this reform have already received their legal assessment in the Decision of the Constitutional Court of Ukraine of 11 March 2020 No. 4-p/2020. In particular, the position that the change in the number and subjects of appointment of members of the High Qualifications Commission of Judges of Ukraine without the introduction of an appropriate transition period is recognised as creating significant obstacles to the functioning of effective

18 The Draft Law of Ukraine of 22 June 2020 No 3711 'On Amendments to the Law of Ukraine "On the Judiciary and the Status of Judges" and some Laws of Ukraine on the Activities of the Supreme Court and Judicial Governance Bodies' <http://w1.c1.rada.gov.ua/pls/zweb2/webproc4_1?pf3511=69228> accessed 19 February 2021.

19 Report on the results of the study 'Attitudes of Ukrainian citizens to the judiciary'. Ukrainian Center for Economic and Political Studies O Razumkova (Kyiv, 2020) <https://rm.coe.int/annex-1-representativesurvey/1680a0c2af> accessed 19 February 2021. 
justice and in some cases making it impossible to exercise everyone's right to access to justice as requirements of the principle of the rule of law. ${ }^{20}$

It should also be noted that such a position was previously set out in the Conclusions of the Venice Commission on amendments to the legislation of Ukraine governing the status of the Supreme Court and judicial authorities, adopted at its 121st plenary session (Venice, 6-7 December 2019). It was emphasised that trust in the judiciary could only grow within a stable system, as persistent institutional instability when reforms follow changes in political power can also be detrimental to public confidence in the judiciary as an independent and impartial institution (para. 13 of the Conclusion). ${ }^{21}$

In addition, the explanatory note to para. 10 of the Bordeaux Declaration 'Judges and Prosecutors in a Democratic Society' states that the precondition for public trust in judges and prosecutors and the basis of their legitimacy and authority is the highest level of professional competence of those holding such positions. ${ }^{22}$ That is why the reform of the judiciary in Ukraine should be at the present stage mediated by personnel reset of its bodies, but in a progressive evolutionary way using the principle of individual responsibility while adhering to the right of everyone to respect for private life. Also, a systematic change in the special training of candidates for judges and the further training of incumbent judges in order to achieve a high level of their competence as a prerequisite for increasing civil society confidence and ensuring the institutional stability of the judiciary is important in this reform.

\section{INTRODUCTION OF A LAWYER'S MONOPOLY ON THE REPRESENTATION OF ANOTHER PERSON IN COURT IN TERMS OF THE RIGHT TO A FAIR TRIAL}

One of the novelties of the national legislation of Ukraine was the introduction of the socalled lawyer's monopoly on certain types of legal services, in particular on the representation of another person in court, as well as protection against criminal charges. And if the latter legal institution is not currently the subject of an active debate on its expediency and necessity, then the exclusive representation of another person in court by a lawyer raises a sharp discourse on the possible risks of restricting the right of access to court.

The foundations of this discourse were laid, in particular, in the Strategy for Reforming the Judiciary and Related Legal Institutions for 2015-2020, approved by the Decree of the President of Ukraine of 20 May 2015 No. 276/2015, ${ }^{23}$ which addressed the need for shortterm definition types of legal aid that can be provided only by a lawyer, in order to improve the quality of legal aid and the quality of justice in general, without restricting the participants in the trial in the right of access to justice.

20 The case No 1-304/2019(7155/19), Judgment of the Constitutional Court of Ukraine of 11 March 2020 No 4-r/2020 <https://zakon.rada.gov.ua/laws/show/v004p710-20> accessed 19 February 2021.

21 CDL-AD(2019)027-e Ukraine 'Opinion on the Legal framework in Ukraine governing the Supreme Court and judicial self-governing bodies, adopted by the Venice Commission at its 121st Plenary Session' (Venice, 6-7 December 2019) <https:/venice.coe.int/webforms/documents/?pdf=CDL$\mathrm{AD}(2019) 027$-e $>$ accessed 19 February 2021.

22 Opinion No 12 (2009) of the Consultative Council of European Judges (CCJE) and Opinion No 4 (2009) of the Consultative Council of European Prosecutors (CCPE) to the attention of the Committee of Ministers of the Council of Europe 'On the relations between Judges and Prosecutors in a democratic society’ <https://rm.coe.int/1680747391 https://rm.coe.int/opinion-no-12-2009-on-the-relationsbetween-judges-and-prosecutors-in-/16806a1fbd > accessed 19 February 2021.

23 The Decree of the President of Ukraine from 20 May 2015 No 276/2015 'On the Strategy for Reforming the Judiciary and Related Legal Institutions for 2015-2020' <https://zakon.rada.gov.ua/rada/ show/276/2015> accessed 19 February 2021 
This perspective was reflected in the constitutional amendments of the Law of Ukraine of 2 June 2016 No. 1401-VIII 'On Amendments to the Constitution of Ukraine (concerning justice), ${ }^{24}$ according to which it is declared that everyone has the right to professional legal assistance (Art. 59 of the Constitution). At the same time, in Chapter VIII of the Constitution of Ukraine 'Justice', Art. $131^{2}$ stipulates that for the provision of such professional legal assistance in Ukraine, there is a bar, the principles of organisation and activity of which are determined by law. In order to guarantee the provision of professional legal assistance, a constitutional rule enshrines that only a lawyer represents another person in court, as well as provides protection from criminal charges.

There is currently no clear legal certainty as to the relationship between the constitutional guarantees of the right of everyone to receive professional legal assistance, by enshrining only the right of a lawyer to represent another person in court and by restricting the right of access to court in such circumstances. This was reflected in the draft Law on Amendments to the Constitution of Ukraine (on the abolition of the lawyer's monopoly) No. 1013 of 29 August 2019. ${ }^{25}$ Its provisions caused considerable resonance in the professional community concerning the introduction, restriction, and abolition of the lawyer's monopoly on representation of a person in court, as well as the capabilities of the state in the field of legal provision of the right of access to court.

In this context, it should be noted that in Moldavska $v$ Ukraine, the ECtHR, analysing the constitutional restrictions on the representation of another person in court, restated, inter alia, that the right of access to court is not absolute. Even a broader restriction on the free choice of defence counsel, limiting it to a licensed advocate before all courts, may not in itself raise an issue under Art. 6 of the ECHR since specific legal qualifications can be required to ensure the efficient defence of a person. However, such a restriction on the applicant's right must have a sufficient basis in domestic law to avoid being arbitrary. ${ }^{26}$

Thus, the ECtHR, in fact, pointed out that enshrining in the national legislation of Ukraine the representation of another person in court exclusively by a lawyer does not in itself violate the right to a fair trial, and also pointed to the state's legal capacity to access to court, due to current needs and resources. Therefore, on this basis, it can be concluded that the existence of such restrictions on access to court cannot be unequivocally recognised as a violation of the right to a fair trial.

\section{MOTIVATION OF COURT DECISIONS IN THE ASPECT OF THE RIGHT TO A FAIR TRIAL}

One of the pressing issues of national law enforcement is the problem of proper motivation of court decisions. In this context, it should be noted that in accordance with Art. 6 para. 1 of the ECHR, judgments of courts and tribunals should adequately state the reasons on which they are based in order to show that the parties were heard and to ensure public scrutiny of the administration of justice. However, Art. 6 para.1 cannot be understood as requiring a detailed answer to every argument raised by the parties. Accordingly, the question of

24 The Law of Ukraine of 2 June 2016 No 1401-VIII 'On Amendments to the Constitution of Ukraine (Regarding Justice)' <https://zakon.rada.gov.ua/rada/show/1401-19> accessed 19 February 2021.

25 The Draft Law 'On Amendments to the Constitution of Ukraine (Concerning the Abolition of the Lawyer's Monopoly) of 29 August 2019 No $1013<$ https://w1.c1.rada.gov.ua/pls/zweb2/ webproc4_1?pf3511=66242> accessed 19 February 2021.

26 Moldavska v Ukraine App no 43464/18 para 26 <http://hudoc.echr.coe.int/eng?i=001-193900> accessed 19 February 2021. 
whether a court has failed to fulfil its obligation to state reasons can only be determined in the light of the circumstances of the particular case. ${ }^{27}$

The legal expert community is currently emphasising that the issue of the validity of a court decision is crucial in the justice system and argues that the state is obliged to resolve problematic issues in this area, which judges themselves cannot resolve on their own.

The draft Law of Ukraine of 25 January 2021 No. 4737 'On Amendments to the Law of Ukraine "On the Judiciary and the Status of Judges" and Other Legal Acts of Ukraine on Motivation of the Decisions of Judges ${ }^{28}$ is an attempt to settle this problem at the current stage of reforming of the Ukrainian judiciary in the direction of ensuring the right to a fair trial. The draft law, in particular, states that if the court in its decision did not provide a legal assessment of all the arguments of the parties in respect of which the dispute arose, such a dispute is considered unresolved. ${ }^{29}$

The proposals outlined above are aimed at forming a more responsible attitude of judges to the consideration of cases and decision-making, and therefore at finding additional guarantees to ensure everyone's right to a fair trial. In such circumstances, they can be described as timely and promising.

At the same time, proposals to give the parties the right to independently prepare a draft text of a court decision in a specific case, which has an auxiliary (advisory) nature, and formally submit it to the case file are debatable. It is seen that the introduction of such a procedural possibility may threaten to violate the principles of fairness and impartiality of the court, as one of the important reasons for improper motivation of court decisions is the lack of time due to excessive workload on judges due to the lack of staffing of the judiciary. Addressing this issue should balance the burden on judges and create objective conditions for proper motivation of court decisions.

\section{CONCLUSIONS}

The key threats to the effective exercise of the right of access to court in Ukraine include the inconsistency of the system of local general courts with the new administrative-territorial structure on the district level, the lack of clear and unambiguous criteria for delimitation of subject-matter jurisdiction, the problem of quantitative and qualitative staffing and the resulting low level of public confidence in the judiciary. Establishment by Ukraine of statutory procedural restrictions, in particular, the obligation to pay court fees for filing a lawsuit, the introduction of criteria for the insignificance of the case, which makes it impossible to appeal, securing a lawyer's monopoly on representation of another person in court, cannot be considered a violation of the convention right to a fair trial if such restrictions are justified and proportionate to the lawful purpose of their establishment, do not violate the very essence of the right to go to court. In the search for additional guarantees to ensure everyone's right to a fair trial, legislative initiatives are introduced aimed at forming a more responsible attitude of judges to the consideration of cases and making reasoned decisions,

27 Salov $v$ Ukraine App no 65518/01 para 89 <http://hudoc.echr.coe.int/eng?i=001-70096> accessed 19 February 2021.

28 The Draft Law 'On Amendments to the Law of Ukraine "On the Judiciary and the Status of Judges" and other Legislative Acts of Ukraine on the Motivation of Court Decisions' <http://w1.c1.rada.gov.ua/pls/ zweb2/webproc4_1?pf3511=70891> accessed 19 February 2021.

29 Explanatory note to the draft Law of Ukraine 'On Amendments to the Law of Ukraine "On the Judiciary and the Status of Judges" and other legislative acts of Ukraine on the motivation of court decisions' <http://w1.c1.rada.gov.ua/pls/zweb2/webproc4_1?pf3511=70891> accessed 19 February 2021. 
as well as solving the problem of the excessive workload of judges due to shortcomings in the judiciary as an objective prerequisite for proper motivation of court decisions.

\section{CONTRIBUTORS}

All three authors contributed equally to the intellectual discussion underlying this paper, literature exploration, writing, data collection and analysis and interpretation, reviews, and editing, and accept responsibility for the content of the paper.

Dr. Stefanchuk Maryna is a professor at the Law School, Taras Shevchenko National University of Kyiv, Ukraine. Areas of scholarly interests include prosecution, judicial systems, and proceedings. ORCID ID: 0000-0002-6239-9091

ResearcherID: M-7224-2018

m.stefanchuk@gmail.com

Dr. Hladun Oleksandr is a Senior Research Fellow, OSCE Project Co-ordinator in Ukraine: conference speaker 'Anticorruption Crisis in Ukraine: Origins, Outcomes and Lessons Learned. IV Kyiv Polilogue' (2020). The European Programme for Human Rights Education for Legal Professionals (HELP): tutor of the course 'Introduction to the European Convention on Human Rights and the European Court of Human Rights' (2018). TOT training participant 'Proofs and evidence in criminal proceedings in the light of the case-law of the European Court of Human Rights' (2018). European Union AntiCorruption Initiative (EUACI): national expert in combatting corruption (2018). Areas of interest: proceedings, criminal law and criminology, and combatting corruption.

ORCID ID: 0000-0003-2220-2394

ResearcherID: AAY-1619-2020

hladunsan@gmail.com

Prof. Stefanchuk Ruslan is an Academic of the National Academy of Legal Sciences of Ukraine. Areas of interest: lawmaking, judicial systems, civil law, and civil procedure. Currently, Prof. Stefanchuk serves as a First Deputy Speaker of the Verkhovna Rada of Ukraine.

ORCID ID: 0000-0001-6385-0131

ResearcherID: M-2450-2018

r.stefanchuk@gmail.com 